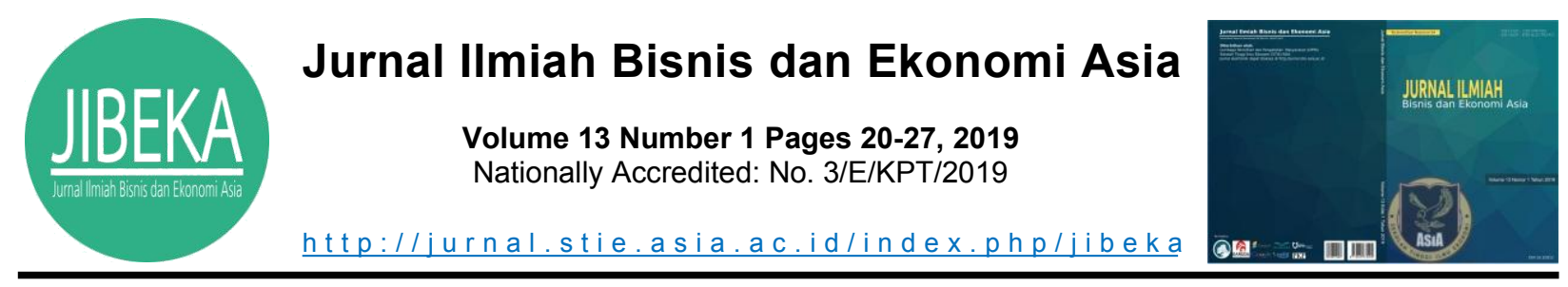

\title{
LITERASI KEUANGAN PADA GENERASI MILENIAL
}

\author{
Mega Noerman Ningtyas* \\ Sekolah Tinggi IImu Ekonomi Asia, Indonesia
}

INFO ARTIKEL

DOI: 10.32812/jibeka.v13i1.111

ISSN-P: 0126-1258

ISSN-E: 2620-875X

Keywords: Financial Literacy, Financial Knowledge, Millennial Generation

\section{ABSTRACT}

Low financial literacy will have an impact on making decisions in everyday life. Making wrong decisions will end in poor and ineffective financial management that can lead to behavior of people who are vulnerable to financial crises and have the potential to suffer losses due to financial sector crime. The level of financial literacy will vary according to the demographic characteristics. Women, minorities and low income groups tend to have low levels of financial literacy. Likewise with age, age determines the point of view of people towards something. Generation $\mathrm{Y}$ is a generation bom in the years 1980-1994 where this generation is very closely related to technology and has different habits with other generations. The purpose of this study is to measure the financial literacy index in the millennial generation. This study uses a type of descriptive research so that researchers describe the index that has been calculated previously. The index is then tested for its influence on financial behavior. The test results show basic and sharia financial literacy has a significant positive effect on financial behavior. This is evidenced by the value of $t$ count of the two variables (basic financial literacy and advanced financial literacy) which is greater than $\mathrm{t}$ table (3.147> 1.97; 2.512> 1.97). The more a person understands the financial concept, the more he is able to manage his finances well

\section{ABSTRAK}

Literasi keuangan yang rendah akan berdampak pada pembuatan keputusan dalam kehidupan sehari-hari. Pembuatan keputusan yang salah akan berakhir pada pengelolaan keuangan yang buruk dan tidak efektif dapat mengakibatkan perilaku masyarakat yang rentan akan krisis keuangan dan berpotensi mengalami kerugian akibat kejahatan di sektor keuangan. Tingkat literasi keuangan akan berbeda-beda sesuai dengan ciri-ciri demografinya. Wanita, kaum minoritas dan golongan berpenghasilan rendah cenderung memiliki tingkat literasi keuangan yang rendah. Begitu juga dengan usia, usia sangat menentukan sudut pandang orang terhadap sesuatu. Generasi $Y$ adalah generasi yang lahir di rentang tahun 1980-1994 dimana generasi ini sangat erat dengan teknologi dan memiliki kebiasaan yang berbeda dengan generasi lainnya. Tujuan dari penelitian ini adalah mengukur indeks literasi keuangan pada generasi milenial. Penelitian ini menggunakan jenis penelitian deskriptif sehingga peneliti menjabarkan indeks yang telah dihitung sebelumnya. Indeks tersebut kemudian diuji pengaruhnya dengan perilaku keuangan. Hasil pengujian menunjukkan literasi keuangan dasar dan syariah berpengaruh positif signifikan terhadap perilaku keuangan. Hal tersebut dibuktikan dengan nilai $t$ hitung kedua variabel (literasi keuangan dasar dan literasi keuangan lanjutan) yang lebih besar daripada $t$ tabel $(3,147>1,97 ; 2,512>1,97)$. Semakin seseorang paham akan konsep keuangan maka semakin ia mampu mengelola dengan baik keuangannya. (c) 2019 Jibeka. All rights reserved

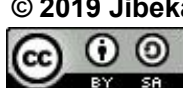




\section{Pendahuluan}

Dalam dekade terakhir literasi keuangan menjadi isu utama dan menjadi salah satu kebijakan yang sedang gencar-gencarnya dilakukan oleh pemerintah. Hasil survei dari Household Balance Sheet Survey (HBSS) oleh Bank Indonesia di tahun 2011 menyatakan bahwa hanya $43,57 \%$ rumah tangga yang memiliki akun tabungan di bank, sedangkan hanya $19,58 \%$ rumah tangga yang dapat mengakses pinjaman di bank. Sisanya adalah pada lembaga keuangan non bank (koperasi dan lembaga keuangan mikro) dan lembaga non keuangan (kolega, tetangga, rentenir, warung dan lain-lain). Cole, et al., (2011) memberikan 2 pandangan terkait keterbatasan akan permintaan layanan keuangan yang formal (Cole, Sampson, \& Zia, 2011). Pertama, masyarakat berpenghasilan rendah tidak menuntut layanan jasa keuangan yang formal dengan alasan biaya yang dibutuhkan cukup mahal. Kedua, banyak masyarakat berpenghasilan tinggi tidak familiar menggunakan produk keuangan sehingga hal tersebut menyebabkan permintaan akan layanan jasa keuangan menurun. Hal ini mengimplikasikan bahwa pengetahuan keuangan yang rendah akan menurunkan permintaan suatu layanan jasa keuangan. Pengetahuan keuangan ini sangat erat hubungannya dengan literasi keuangan.

Literasi keuangan merupakan kemampuan individu dalam mengaplikasikan pengelolaan keuangan, baik dalam mendapatkan dan mengevaluasi informasi yang umum diperuntukkan untuk pengambilan keputusan dan melihat konsekuensi yang diterima. Hasil survei yang dilakukan oleh OJK tahun 2016, tingkat literasi keuangan di Indonesia adalah $29,7 \%$ dimana angka tersebut masih di bawah negara ASEAN lainnya, seperti Filipina (27\%), Malaysia $(66 \%)$, Thailand $(73 \%)$ dan Singapura (98\%). Tingkat literasi keuangan yang rendah dilatarbelakangi karena industri keuangan sudah semakin kompleks dan rata-rata masyarakat kurang mampu menghadapi perubahan tersebut (Arceo-Gomez \& Villagomez, 2017). Ada kekhawatiran besar yang dirasakan pemerintah bahwa masyarakat cenderung kurang memiliki pengetahuan tentang konsep keuangan yang mereka butuhkan. Kurangnya pengetahuan ini akan berdampak pada pembuatan keputusan dalam kehidupan sehari-hari, mereka akan sulit membuat keputusan yang paling menguntungkan bagi kesejahteraan ekonominya (financial well being) seperti memiliki hutang berlebih. Pembuatan keputusan yang salah akan berakhir pada pengelolaan ekonomi yang buruk dan tidak efektif dapat mengakibatkan perilaku masyarakat yang rentan akan krisis keuangan (Braunstein \& Welch, 2002) dan berpotensi mengalami kerugian akibat kejahatan (fraud) di sektor keuangan seperti penipuan investasi bodong.

Tingkat literasi keuangan sangat dipengaruhi oleh demografi dari individu tersebut. Wanita, kaum minoritas dan golongan berpenghasilan rendah cenderung memiliki tingkat literasi keuangan yang rendah (Amari \& Jarboui, 2015; de Bassa Scheresberg, 2013). Begitu pula dengan usia dimana sangat menentukan sudut pandang orang terhadap sesuatu. Generasi Y adalah generasi yang lahir di rentang tahun 1980-1994. Generasi ini merupakan generasi yang percaya diri, ekspresif, liberal, bersemangat dan terbuka pada tantangan, karakteristik yang sangat berbeda dengan generasi pendahulunya yaitu $X$ (lahir antara 1963-1977). Generasi $Y$ atau yang biasa disebut dengan milenial, mereka tumbuh bersama lahirnya komputer dan internet sehingga dapat dikatakan mereka memiliki kecerdasan alam dan keterampilan dalam menggunakan teknologi baru (Carrasco-Gallego, 2017). Setiap generasi memiliki gaya hidup yang berbeda-beda. Generasi ini terbiasa dengan barang yang selalu up to date, lebih mementingkan liburan untuk memenuhi keinginan swafoto di tempat yang indah dibandingkan memenuhi kebutuhan hidup utamanya, serta seringkali menghabiskan waktu di kafe mahal atau bahkan membeli baju rancangan desainer.

Beberapa penelitian sebelumnya telah menguji tingkat literasi keuangan pada anak muda (Das, 2017; de Bassa Scheresberg, 2013; Friedline \& West, 2016; Mottola, 2014). Hasil penelitian menunjukkan bahwa tingkat literasi keuangan dewasa muda masih sangat rendah meskipun mereka tergolong financially active_terbukti dari kepemilikan kartu kredit. Tingkat literasi keuangan akan meningkat seiring dengan meningkatnya pendidikan. Diantara generasi lainnya, milenial menunjukkan tingkat literasi keuangan yang paling rendah-hanya $24 \%$ saja responden yang dapat menjawab pertanyaan yang diajukan 
dengan benar, sedangkan generasi $X 38 \%$, baby boomer $48 \%$ dan silent generation $55 \%$ (Mottola, 2014). Tingkat literasi keuangan itu juga akan berbeda di tiap-tiap negara. Australia, Kanada, Denmark, Jerman, Israel, Belanda dan Inggris dimana sudah lebih dari $65 \%$ penduduknya yang terliterasi dengan baik sedangkan untuk Asia Selatan hanya 25\% penduduknya yang terliterasi. Ada perbedaan yang cukup signifikan antara negara maju dan negara berkembang (Klapper, Lusardi, \& Oudheusden, 2015).

Sebelumnya penelitian di Indonesia hanya berfokus pada pengukuran indeks literasi keuangan individu pada berbagai profesi, seperti mahasiswa (Welly, Kardinal, \& Juwita, n.d.) dosen (Setyawati \& Suroso, 2016), karyawan (Sobaya, Hidayanto, \& Safitri, 2016) dan para pelaku UMKM (Ariwibawa, 2016; Hakim, Baihaqi, \& Kunaifi, 2017; Puspitaningtyas, 2018). Penelitian literasi keuangan yang berfokus pada populasi penduduk tertentu yaitu generasi milenial masih sangat terbatas. Pada penelitian ini menggunakan indeks literasi keuangan yang dikembangkan oleh DEFINIT-SEADI-OJK (2013) dimana literasi keuangan dibagi menjadi 2 indikator yaitu literasi keuangan dasar dan lanjutan. Pada studi ini menambahkan indikator lain yaitu literasi keuangan syariah dimana indeks tersebut dikembangkan oleh Antara et al., (2016) (Antara, Musa, \& Hassan, 2016). Berdasarkan latar belakang yang telah dipaparkan diatas maka studi ini bertujuan untuk menguji pengaruh literasi keuangan terhadap perilaku keuangan pada generasi milenial.

\section{Metode Penelitian}

Pada penelitian empiris ini pengumpulan data dilakukan menggunakan kuisioner online yang disebarkan pada generasi milenial (lahir antara tahun 1980-1994). Total responden berjumlah 225 responden. Kuisioner terdiri dari 5 bagian yaitu demografi ( 8 pertanyaan), literasi keuangan dasar (11 pertanyaan), literasi keuangan syariah (17 pertanyaan) dan perilaku keuangan (10 pertanyaan).

Metode penelitian yang digunakan adalah deskriptif kuantitatif. Variabel yang digunakan adalah perilaku keuangan sebagai variabel terikat, literasi keuangan sebagai variabel bebas serta gender dan status pernikahan sebagai variabel kontrol. Karakteristik responden dalam penelitian ini meliputi usia, jenis kelamin, status pernikahan, agama, pendidikan terakhir, jenis pekerjaan, tempat tinggal, wilayah tempat tinggal dan pendapatan per bulan.

Perhitungan indeks literasi keuangan mengikuti apa yang telah dilakukan oleh OJK dengan merujuk dari penelitian Lusardi dan Mitchell (Lusardi \& Mitchell, 2014). Pada tiaptiap item pertanyaan pada literasi keuangan akan diberi skor seperti demikian. Nilai 1 untuk jawaban benar dan 0 untuk jawaban salah dan tidak tahu. Kemudian masing-masing item akan diberikan bobot untuk mendapatkan indeks literasi keuangan.

Dimana,

$$
\text { Simple_basic_Wi }=1 / \mathrm{N}
$$

Simple_basic_Wi : bobot untuk item pertanyaan $i$ di Literasi Keuangan Dasar $\mathrm{N}$ : jumlah item pertanyaan Literasi Keuangan Dasar

Dimana,

$$
\text { Simple_sharia_Wk }=1 / \mathrm{L}
$$

Simple_sharia_Wk : bobot untuk item pertanyaan $k$ di Literasi Keuangan Syariah $\mathrm{L}$ : jumlah item pertanyaan Literasi Keuangan Syariah

Dari indeks tersebut akan dihasilkan suatu angka 0-100. Dari indeks tersebut kemudian dapat diklasifikasikan menjadi 3 kategori yaitu:

1. $0 \leq \mathrm{FLI} \leq 60$ maka dikategorikan sebagai indeks literasi keuangan rendah;

2. $60 \leq \mathrm{FLI} \leq 80$ maka dikategorikan sebagai indeks literasi kuangan moderat;

3. FLI $\geq 80$ maka dikategorikan sebagai indeks literasi keuangan tinggi. 
Pada perilaku keuangan digunakan skala likert dengan 5 pilihan skala. Pada penelitian ini menggunakan analisis regresi linier berganda dengan program aplikasi Eviews. Dengan penguasaan literasi keuangan diharapkan akan mengarah pada perilaku keuangan yang lebih bertanggung jawa sehingga akan berdampak pada perekonomian negara yang lebih kuat.

\section{III.Hasil Penelitian dan Pembahasan}

Tabel 1. Deskripsi Statistik

\begin{tabular}{|c|c|c|}
\hline Variabel & Jumlah Responden & Prosentase \\
\hline \multicolumn{3}{|l|}{ Jenis Kelamin } \\
\hline Laki-laki & 79 & $35 \%$ \\
\hline Perempuan & 147 & $65 \%$ \\
\hline \multicolumn{3}{|l|}{ Usia } \\
\hline 24-28 tahun & 146 & $64.60 \%$ \\
\hline 28-33 tahun & 33 & $14.60 \%$ \\
\hline$>33$ tahun & 12 & $5.30 \%$ \\
\hline \multicolumn{3}{|l|}{ Agama } \\
\hline Islam & 202 & $89.40 \%$ \\
\hline Kristen Protestan & 11 & $4.90 \%$ \\
\hline Kristen Katolik & 10 & $4.40 \%$ \\
\hline Hindu & 3 & $1.30 \%$ \\
\hline Budha & - & - \\
\hline Konghucu & - & - \\
\hline \multicolumn{3}{|l|}{ Status } \\
\hline Belum menikah & 153 & $67.70 \%$ \\
\hline Sudah menikah & 70 & $31 \%$ \\
\hline Cerai & 3 & $1.30 \%$ \\
\hline \multicolumn{3}{|l|}{ Pendidikan Terakhir } \\
\hline Tidak tamat SD & - & - \\
\hline SD & - & - \\
\hline SMP & - & 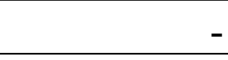 \\
\hline SMA & 41 & $18.10 \%$ \\
\hline S1 & 139 & $61.50 \%$ \\
\hline S2 & 46 & $20.40 \%$ \\
\hline \multicolumn{3}{|l|}{ Pekerjaan } \\
\hline Pegawai dan profesional & 130 & $57.50 \%$ \\
\hline Mahasiswa & 38 & $16.80 \%$ \\
\hline Pengusaha & 12 & $5.30 \%$ \\
\hline Dosen & 9 & $4 \%$ \\
\hline Ibu Rumah Tangga & 9 & $4 \%$ \\
\hline Lain-lain & 28 & $12.400 \%$ \\
\hline \multicolumn{3}{|l|}{ Tempat Tinggal } \\
\hline Jawa & 202 & $89.40 \%$ \\
\hline
\end{tabular}




\begin{tabular}{|l|r|r|}
\hline Luar Jawa & 24 & $10.60 \%$ \\
\hline Wilayah Tempat Tinggal & 196 & $86.70 \%$ \\
\hline Perkotaan & 30 & $13.30 \%$ \\
\hline Pedesaan & 29 & $12.80 \%$ \\
\hline Pendapatan Per Bulan & 54 & $23.90 \%$ \\
\hline$<1.000 .000$ & 70 & $31 \%$ \\
\hline $1.000 .000-2.500 .000$ & 73 & $32.30 \%$ \\
\hline $2.600 .000-5.000 .000$ & & \\
\hline$>5.000 .000$ & & \\
\hline
\end{tabular}

Pada Tabel 1 diatas, mayoritas responden yang mengisi kuisioner ini adalah 65\% perempuan yang berada pada rentang umur 24-28 tahun. Mayoritas responden beragama islam $(89,4 \%)$, belum menikah $(67,7 \%)$ dan pendidikan terakhirnya adalah sarjana $(61,5 \%)$. Berdasarkan pekerjaan dan pendapatan per bulan, mayoritas responden adalah pegawai dan profesional (57,5\%) dengan pendapatan 2.600.000-5.000.000 per bulan. Jika berdasarkan tempat tinggal, mayoritas responden berasal dari Jawa $(89.4 \%)$ yang berada di wilayah perkotaan $(86,7 \%)$.

Berdasarkan hasil perhitungan seluruh instrumen untuk mengukur pengaruh literasi keuangan terhadap perilaku keuangan, diketahui nilai $r$ hitung signifikan pada level $5 \%$ sehingga dapat disimpulkan bahwa semua item pada variabel literasi keuangan dan perilaku keuangan dinyatakan valid yang dapat dilihat pada Tabel 2 dan Tabel 3.

Tabel 2. Validitas Perilaku Keuangan

\begin{tabular}{|l|l|l|}
\hline Item & R hitung & Validitas \\
\hline Perilaku Keuangan & & \\
\hline Soal 1 & $0.461^{* *}$ & Valid \\
\hline Soal 2 & $0.485^{* *}$ & Valid \\
\hline Soal 3 & $0.391^{* *}$ & Valid \\
\hline Soal 4 & $0.642^{* *}$ & Valid \\
\hline Soal 5 & $0.208^{* *}$ & Valid \\
\hline Soal 6 & $0.409^{* *}$ & Valid \\
\hline Soal 7 & $0.618^{* *}$ & Valid \\
\hline Soal 8 & $0.680^{* *}$ & Valid \\
\hline Soal 9 & $0.588^{* *}$ & Valid \\
\hline Soal 10 & $0.553^{* *}$ & Valid \\
\hline
\end{tabular}

Tabel 3. Validitas Literasi Keuangan

\begin{tabular}{|l|l|l|}
\hline Item & R Hitung & Validitas \\
\hline Literasi Keuangan & & \\
\hline Soal 1 & 0.122 & Tidak Valid \\
\hline Soal 2 & 0.082 & Tidak Valid \\
\hline Soal 3 & $0.214^{* *}$ & Valid \\
\hline Soal 4 & $0.534^{* *}$ & Valid \\
\hline Soal 5 & $0.450^{* *}$ & Valid \\
\hline Soal 6 & $0.407^{* *}$ & Valid \\
\hline Soal 7 & $0.459^{* *}$ & Valid \\
\hline Soal 8 & $0.305^{* *}$ & Valid \\
\hline Soal 9 & $0.590^{* *}$ & Valid \\
\hline Soal 10 & $0.508^{* *}$ & Valid \\
\hline
\end{tabular}


\begin{tabular}{|l|l|l}
\hline Soal 11 & $0.468^{* *}$ & Valid
\end{tabular}

Dari hasil uji regresi menunjukkan model penelitian sebagai berikut:

\title{
$F B=37,878+1,083 B F L+1,421 S F L-1,173$ Gender+0,622MaritalStatus+e
}

\author{
Keterangan: \\ FB \\ : Perilaku Keuangan \\ BFL \\ : Literasi Keuangan Dasar \\ SFL \\ : Literasi Keuangan Syariah \\ Gender \\ : Jenis Kelamin (variabel kontrol) \\ MaritalStatus \\ : Status Pernikahan (variabel kontrol)
}

Data telah memenuhi aturan asumsi klasik sehingga data kemudian dapat diuji dengan regresi linier berganda. Analisis regresi linier berganda ini digunakan untuk mengetahui pengaruh variabel literasi keuangan (variabel bebas), gender dan status pernikahan (variabel kontrol) terhadap perilaku keuangan (variabel terikat). Dari hasil pengujian, menyatakan bahwa koefisien determinasi sebesar $4,78 \%$. Nilai signifikansi pada Uji $F$ (uji simultan) menunjukkan angka 0,010 sehingga dapat disimpulkan model yang dibangun layak (fit) untuk menjelaskan perilaku keuangan. Nilai konstanta sebesar 37,878 berarti bahwa besaran perilaku keuangan yang tidak dipengaruhi oleh literasi keuangan dasar, literasi keuangan syariah, gender dan status pernikahan namun dipengaruhi oleh variabel lain yang tidak termasuk ke dalam model.

Jika dilihat dari uji parsial (uji t-statistik) dimana uji tersebut menunjukkan bagaimana pengaruh masing-masing variabel bebas terhadap variabel terikat sehingga kita bisa mengambil kesimpulan apakah hipotesis diterima atau ditolak. Dengan tingkat signifikansi $5 \%$ dan pengujian dua arah maka didapatkan nilai $t$ tabel sebesar $1,97(k=4, d f=186)$. Berdasarkan tabel di bawah, kedua variabel bebas memiliki nilai $\mathrm{t}$ statistik lebih besar daripada nilai t tabel (BFL: 2,1917>1,97; SFL:1,98>1,97). Hal itu menyatakan bahwa baik literasi keuangan dasar (BFL) maupun literasi keuangan syariah (SFL) berpengaruh positif signifikan terhadap perilaku keuangan (FB).

\section{Tabel 4. Hasil Uji Regresi Linier Berganda}

\begin{tabular}{|c|c|c|c|c|}
\hline \multicolumn{5}{|c|}{$\begin{array}{l}\text { Dependent Variable: FB } \\
\text { Method: Least Squares } \\
\text { Date: 04/06/19 Time: 18:07 } \\
\text { Sample: } 1190 \\
\text { Included observations: } 190\end{array}$} \\
\hline Variable & Coefficient & Std. Error & $\mathrm{t}$-Statistic & Prob. \\
\hline $\mathrm{C}$ & 37.87814 & 0.976180 & 38.80243 & 0.0000 \\
\hline BFL & 1.083547 & 0.494340 & 2.191907 & 0.0296 \\
\hline SFL & 1.421649 & 0.717359 & 1.981783 & 0.0490 \\
\hline GENDER & -1.173433 & 0.712065 & -1.647930 & 0.1011 \\
\hline MARITALSTATUS & 0.622762 & 0.709717 & 0.877479 & 0.3814 \\
\hline R-squared & 0.068012 & \multicolumn{2}{|c|}{ Mean dependent var } & 39.31053 \\
\hline Adjusted R-squared & 0.047861 & \multicolumn{2}{|c|}{ S.D. dependent var } & 4.747976 \\
\hline S.E. of regression & 4.632962 & \multicolumn{2}{|c|}{ Akaike info criterion } & 5.930233 \\
\hline Sum squared resid & 3970.903 & \multicolumn{2}{|c|}{ Schwarz criterion } & 6.015681 \\
\hline Log likelihood & -558.3722 & \multirow{2}{*}{\multicolumn{2}{|c|}{$\begin{array}{l}\text { Hannan-Quinn criter. } \\
\text { Durbin-Watson stat }\end{array}$}} & 5.964847 \\
\hline F-statistic & 3.375091 & & & 2.079979 \\
\hline Prob(F-statistic) & 0.010796 & \multicolumn{2}{|c|}{ Durbin-Watson stat } & \\
\hline
\end{tabular}

Sumber: Data diolah

$*^{* * *},{ }^{* * *}$ : signifikan pada level $10 \%, 5 \%$ dan $1 \%$ 
Dalam penelitian ini menggunakan variabel dummy yaitu jenis kelamin (gender; 0 : laki-laki , 1: perempuan ) dan status perkawinan (marital status; 0: belum menikah, 1: menikah). Hal ini berarti bahwa jenis kelamin dan status perkawinannya mempengaruhi seseorang dalam bertindak. Berdasarkan hasil pengujian diatas, perilaku keuangan wanita lebih baik dibandingkan laki-laki. Begitu pula dengan status perkawinan, individu yang telah menikah memiliki perilaku keuangan yang lebih baik dibandingkan individu yang belum menikah. Namun nilai $t$ statistik dari variabel jenis kelamin $(-1,647>-1,97)$ dan status perkawinan $(0,877<1,97)$ lebih kecil daripada t tabel menjadikan pengaruh kedua variabel tersebut tidak signifikan.

Hasil pengujian diatas menunjukkan bahwa semakin seseorang mengetahui konsepkonsep keuangan (baik konsep keuangan dasar dan keuangan syariah) maka semakin mampu pula seseorang tersebut menerapkan perilaku keuangan yang baik. Perilaku keuangan yang baik dapat dilihat dari perencanaan keuangan yang dibuatnya meliputi kemampuan ia menabung, kedisiplinan membayar tagihan di setiap bulannya dan lain-lain. Hal ini sesuai dengan pendapat Lusardi \& Mitchell (2014) yaitu perencanaan keuangan yang baik didukung oleh adanya pengetahuan yang memadai yang dimiliki oleh individu (Lusardi \& Mitchell, 2014). Orang-orang yang mengetahui prinsip dasar keuangan akan memiliki rencana pensiun yang baik, memiliki kekayaan lebih besar serta lebih baik dalam menghindari utang konsumtif. Hal ini disebabkan mereka mampu menggunakan uang dengan bijak sehingga berdampak pada penambahan manfaat ekonomi bagi dirinya. Begitu pula dalam hal investasi, generasi milenial harus memiliki literasi keuangan yang cukup dalam menentukan visi dan misi serta langkah untuk menentukan tujuan keuangan yang akan dicapai. Dengan memiliki pengetahuan keuangan yang baik maka individu bisa memilih berbagai macam produk investasi dan menimbang mana produk yang menguntungkan baginya.

Generasi milenial yang terbiasa dengan konsumerisme dan hedonisme, pada penelitian ini menunjukkan literasi keuangan yang cukup tinggi. Mereka mulai sadar bahwa perilaku keuangan yang baik akan mengarahkannya pada kondisi masa depan yang lebih baik pula. Pengaruh literasi keuangan terhadap perilaku keuangan tidak terbatas pada jenis kelamin dan status perkawinan. Baik laki-laki dan wanita, menikah ataupun belum, perilaku keuangan ditentukan oleh satu-satunya faktor yaitu pengetahuan. Di era global sekarang, telah banyak bermunculan perusahaan penyedia jasa layanan konsultasi keuangan (financial advisor) yang memberikan edukasi kepada masyarakat akan pentingnya pengelolaan keuangan yang baik seperti BigAlpha ID dan Jouska.id. Mereka membidik edukasinya kepada para anak muda Indonesia.

\section{Kesimpulan}

Berdasarkan penelitian yang telah dilakukan dapat disimpulkan bahwa literasi keuangan dasar dan literasi keuangan syariah berpengaruh positif signifikan terhadap perilaku keuangan. Hal tersebut dibuktikan dengan nilai $t$ hitung dari kedua variabel bebas tersebut lebih dari $t$ tabel. Variabel kontrol yang digunakan pada penelitian ini adalah jenis kelamin dan status perkawinan. Wanita dan individu yang telah menikah cenderung memiliki perilaku keuangan yang baik. Namun, dari hasil pengujian di atas, kedua variabel kontrol tersebut tidak berpengaruh signifikan terhadap perilaku keuangan. Hal tersebut berarti bahwa mereka sadar atau melek keuangan namun tidak mempraktekan perilaku keuangan yang baik. Pada penelitian selanjutnya bisa ditambahkan variabel kontrol lainnya seperti usia, pendidikan dan lain sebagainya agar memberikan hasil yang lebih robust.

\section{Daftar Pustaka}

Amari, M., \& Jarboui, A. (2015). Financial literacy and economics education among young adults: An observation from Tunisia. Journal of Business \& Finance Librarianship, 20(3), 209-219. 
Antara, P. M., Musa, R., \& Hassan, F. (2016). Bridging Islamic Financial Literacy and Halal Literacy: The Way Forward In Halal Ecosystem. Procedia Economics and Finance, 37, 196-202.

Arceo-Gomez, E. O., \& Villagomez, A. (2017). Financial literacy among Mexican high school teenagers. International Review of Economics Education, 24, 1-17.

Ariwibawa, D. (2016). Pengaruh Literasi Terhadap Kinerja Dan Keberlangsungan UMKM di Jawa Tengah. Siasat, 20(1), 1-13.

Braunstein, S., \& Welch, C. (2002). Financial literacy: An overview of practice, research, and policy. Fed. Res. Bull, 88, 445.

Carrasco-Gallego, J. A. (2017). Introducing economics to millennials. International Review of Economics Education, 26, 19-29.

Cole, S., Sampson, T., \& Zia, B. (2011). Prices or knowledge? What drives demand for financial services in emerging markets? The Journal of Finance, 66(6), 1933-1967.

Das, S. C. (2017). Financial Literacy among Indian Millennial Generation and their Reflections on Financial Behaviour and Attitude : .... (September).

de Bassa Scheresberg, C. (2013). Financial literacy and financial behavior among young adults: Evidence and implications. Numeracy, 6(2), 1-21.

Friedline, T., \& West, S. (2016). Financial education is not enough: Millennials may need financial capability to demonstrate healthier financial behaviors. Journal of Family and Economic Issues, 37(4), 649-671.

Hakim, M. S., Baihaqi, I., \& Kunaifi, A. (2017). Value Chain Development As Alternative Method For Mapping Waste Management. Journal of Innovation in Business and Economics, 1(01), 11-18.

Klapper, L., Lusardi, A., \& Oudheusden, P. Van. (2015). Financial literacy around the world. Washington DC: World Bank.

Lusardi, A., \& Mitchell, O. S. (2014). The economic importance of financial literacy: Theory and evidence. Journal of Economic Literature, 52(1), 5-44.

Mottola, G. R. (2014). The Financial Capability of Young Adults - A Generational View. FINRA Foundation Financial Capability Insights, March(March), 1-12. https://doi.org/10.13140/RG.2.1.3800.5281

Puspitaningtyas, Z. (2018). Manfaat Literasi Keuangan Bagi Business Sustainability.

Setyawati, I., \& Suroso, S. (2016). Sharia financial literacy and effect on social economic factors (survey on lecturer in Indonesia). International Journal of Scientific \& Technology Research, 5(2), 92-102.

Sobaya, S., Hidayanto, M. F., \& Safitri, J. (2016). Pengaruh Literasi Keuangan Dan Lingkungan Sosial Terhadap Perencanaan Keuangan Pegawai Di Universitas Islam Indonesia Yogyakarta. MADANIA: JURNAL KAJIAN KEISLAMAN, 20(1), 115-128.

Welly, W., Kardinal, K., \& Juwita, R. (n.d.). Analisis Pengaruh Literasi Keuangan Terhadap Keputusan Investasi Di Stie Multi Data Palembang. 